DOI: https://doi.org/10.21009/hayula.006.01.06

\title{
Perubahan Pemahaman Mahasiswa Terhadap Makna Keimanan/ Kekafiran Ahli Kitab dengan Metode Tematik Digital Quran
}

\author{
M. Wildan Bin H.M. Yahya \\ Fakultas Dakwah, Universitas Islam Bandung \\ Email: wildanyahya.1960@gmail.com
}

Munawar Rahmat

Program Studi Ilmu Pendidikan Agama Islam, FPIPS, UPI

Email: munawarrahmat.pai@upi.edu

Artikel Diterima: 22 Desember 2021, Revisi: 30 Desember 2022, Disetujui: 17 January 2022

\begin{abstract}
Muslim students view Ahli Kitab (followers of a non-Islamic religion) as kafir. As a result, they refuse non-Muslims to hold public positions because they are infidels. Whereas the Qur'an confirms that among the Ahli Kitab, some believe, are trustworthy, and are pious. The best solution is to develop a Quran-based Islamic Religious Education (PAI) learning model. The research aims to produce a digital Quran thematic learning model to understand the term Ahli Kitab in Al-Quran. Quasi R\&D research method. Model testing at UNISBA and UPI. The themes discussed: the meaning of believing, the meaning of unbelievers, and the meaning of the People of the Book in the Al-Quran. The results of the study describes syntax model digital quran thematic and students' religious mindsets changed. At first, they associated faith and disbelief with religious identity. As for after college, they associate it with good and evil characters. According to the students, there are people of the Book who believe, but more are unbelievers. The implication is that the digital Quran thematic model is quite effective in changing the religious mindset of students.
\end{abstract}

Keywords: method of thematic digital Quran, the meaning of believer, the meaning of unbeliever, the meaning of Ahli Kitab.

\begin{abstract}
Abstrak
Mahasiswa Muslim UNISBA dan UPI memandang Ahli Kitab (pengikut agama nonIslam) sebagai kafir. Akibatnya, mereka menolak non-Muslim untuk menduduki jabatan publik karena mereka kafir. Padahal Al-Qur'an menegaskan bahwa di antara Ahli Kitab ada yang beriman, amanah, dan pelaku kebajikan. Solusi terbaik dengan mengembangkan model pembelajaran Pendidikan Agama Islam (PAI) berbasis AlQuran, karena Al-Quran merupakan referensi pertama dan utama Islam. Penelitian bertujuan menghasilkan metode pembelajaran tematik digital Quran untuk memahami istilah Ahli Kitab dalam Al-Quran. Metode penelitian kuasi R\&D. Teknik pengumpulan data menggunakan data hasil uji-coba model metode tematik digital al quran di UNISBA dan UPI. Hasil penelitian mendeskripsikan langkah metode tematik alquran digital dan pola pikir keagamaan mahasiswa tentang makna keimanan ahli kitab berubah secara logis, sebelumnya mereka mengaitkan keimanan dan kekafiran
\end{abstract}


dengan identitas agama. Adapun setelah kuliah, mereka mengasosiasikannya dengan karakter baik dan buruk. Implikasinya, model pembelajaran tematik digital Qur'an cukup efektif mengubah pola pikir keagamaan mahasiswa.

Kata Kunci: makna beriman; makna kafir; makna Ahli Kitab; metode tematik digital Quran

\section{Pendahuluan}

Pendidikan Agama Islam (PAI) di perguruan tinggi umum diharapkan dapat menciptakan mahasiswa yang taat beragama, memahami ajaran dasar Islam secara lebih tepat, dan bersikap toleran terhadap penganut agama dan mazhab lain yang berbeda. Hasil studi terdahulu PAI yang damai, moderat, dan toleran lebih dipengaruhi oleh faktor keterbukaan dosen. Adapun faktor lainnya adalah pemilihan materi dan model pembelajaran yang inklusif (Munawar Rahmat, 2018: 59-61).

Bagaimanakah mengajarkan dasar-dasar agama yang lebih tepat kepada mahasiswa, dan apa referensi utamanya? Al-Quran disepakati sebagai sumber utama ajaran Islam. Dalam dua dasawarsa terakhir ini cukup digencarkan gerakan kembali kepada Al-Quran. Bahkan Imam mazhab saja (Imam Hanafi, Maliki, Syafi`i, dan Hanbali) menekankan perlunya umat untuk memahami agama dengan merujuk langsung kepada Al-Quran dan Al-Sunnah (Pasha \& Darban, 2000). Tapi slogan agar umat kembali kepada Al-Qur`an sulit diwujudkan. Penyebab utamanya ada tiga: pertama, tema ajaran (misal: rasul, shalat, ahl al-kitab, dll) bertebaran di berbagai surah; kedua, Kitab Al-Quran sangat tebal (6.236 ayat); dan ketiga, metode tafsirnya sangat sulit. Akibatnya, para mahasiswa tetap saja taqlid kepada ulama, bahkan mereka taqlid kepada pandangan umum masyarakat muslim. Model/metode pembelajaran Tematik Digital Quran diharapkan dapat mengatasi ketiga penyebab kesulitan tersebut.

Ada dua metode induk tafsir Al-Quran yakni bil-mansur (بالمأثور) atau bil-manqul (بالمنقول) dan bil-ra yi (بالرعى). Tapi kedua metode ini tidak mungkin dapat digunakan oleh mahasiswa. (Al-Qattan, 2001) dan (Ash-Shidieqi, 1980) menyebutkan tafsir bil-mansur adalah metode penafsiran dengan cara mengambil rujukan pada Al-Quran, hadist Nabi, dan pendapat sahabat Nabi serta tabi in (murid sahabat Nabi). Dalam kapasitasnya sebagai Nabi dan Rasul tentu saja tafsir Nabi ini disepakati paling benar. Sayangnya, tafsir Nabi yang sampai kepada umat sangat sedikit dan tidak menyinggung fondasi-fondasi agama. Dengan 
wafatnya Nabi Muhammad SAW otomatis berakhir pula periode tafsir ini. Demikianlah keyakinan hampir seluruh kaum muslimin.

Tafsir bil-ma`tsur shahaby, yakni tafsir sahabat-sahabat besar Nabi (terutama empat khalifah dan Ibn Abbas), bahkan tafsir tabi in, bila tafsir Nabi SAW tidak diperoleh, akan tetapi para sahabat dan tabi in tetap berijtihad. Menurut Quraisy (Shihab, 2000) mereka berijtihad sebagai keterpaksaan karena Nabi telah wafat. Tafsir ini selain terbatas, juga tidak luput dari kritik. (Ash-Shiddieqy, 1972) menyebut empat kelemahan tafsir bil-ma`tsur shahaby, yakni: pertama, banyak ditemukan riwayat-riwayat yang disisipkan oleh orangorang Yahudi dan Nasrani dengan tujuan merusak Islam melalui informasi yang tidak dipertanggungjawabkan kebenarannya; kedua, banyak ditemukan usaha-usaha penyusupan kepentingan yang dilakukan oleh aliran-aliran yang dianggap menyimpang; ketiga, tercampur aduknya riwayat-riwayat yang shahih dengan riwayat-riwayat hadits yang sanadnya lemah; dan keempat, banyak ditemukan riwayat Isra`iliyat yang mengandung dongeng-dongeng yang tidak dapat dipertanggungjawabkan.

Tafsir bil-ra yi, yakni tafsir yang bersendikan kepada ijtihad, akal, serta berpegang kepada kaidah-kaidah bahasa dan adat istiadat orang Arab dalam mempergunakan bahasanya (Ash-Shidieqi, 1980). Adapun penyajian tafsirnya ada yang bersifat tahlili dan maudhu $i$.

Tafsir tahlili adalah tafsir satu persatu ayat Al-Quran secara berurutan. Tafsir maudhu $i$ adalah tafsir satu surah Al-Quran secara utuh dan tafsir tematik yakni tafsir per-tema. Tafsir ini membandingkan ayat-ayat Al-Quran satu dengan yang lainnya, yaitu ayat-ayat yang memiliki persamaan atau kemiripan redaksi dalam dua masalah atau kasus yang berbeda atau lebih; dan/atau membandingkan ayat-ayat Al-Quran dengan hadis Nabi Muhammad SAW yang nampak bertentangan serta membandingkan pendapat-pendapat ulama tafsir menyangkut penafsiran al-Qur'an (Shihab, 2000).

Metode maudhu $i$ tidak mengkaji semua ayat melainkan ayat-ayat yang mewakili term tersebut. Kemudian dikaji pula asbabun nuzul-nya yakni sebab-sebab turunnya suatu ayat. (Al-Sadr, 1990; al-Farmawi, 1977). Kedua metode tafsir ini hanya bisa dilakukan oleh ulama tafsir yang sangat ahli, tidak mungkin bisa digunakan oleh mahasiswa. 
Metode hermeuneutika dalam menafsirkan Al-Quran yang lebih bebas, antara lain dilakukan Hasan Hanafi, tapi oleh sebagian pakar dicurigai dipengaruhi gaya penafsiran Bible (Muhsin, 2010). Metode ini tidak mungkin juga dilakukan oleh mahasiswa umum karena mereka tidak memiliki dasar-dasar ilmu tafsir yang memadai.

Afandi (2001) menggunakan metode tafsir maudhu i-nya Al-Qarafi ketika mengkaji makna al-wasilata. Menurut Al-Qarafi (Afandi, 2001) ada tiga standard untuk menafsirkan istilah-istilah yang dipakai dalam Al-Quran, yakni: sesuai dengan pengertian bahasa dari tradisi masyarakat zaman Nabi Muhammad SAW (konteks sosio-kultural); sesuai semantik bahasa (wadh $i$, yakni sesuai arah dan tujuan yang dikandung); dan upaya menemukan arti yang diyakini sesuai dengan kehendak Allah. Tafsir maudhu $i$-nya Al-Qarafi ini disebut Afandi sebagai metode tafsir yang lebih mudah dan relatif lebih aman. Afandi mencontohkan pemaknaan al-wasilata dalam QS 5/Al-Maidah ayat 35, menurutnya, al-wasilata tidak bisa dimaknai "wasilah" (perantara), karena makna al-wasilata adalah "seorang perantara" (bukan perantara); maksudnya, seorang perantara menuju Tuhan. Dengan dimaknai wasilah maka masyarakat muslim menggunakan Asma`ul Husna, amal saleh, atau seorang Wali walau sudah wafat dalam berdo`a agar do`anya lebih cepat dikabulkan Tuhan. Praktek seperti ini tidak ada salahnya. Tapi memaknai al-wasilata dengan “wasilah' (perantara) tidaklah benar. Makna al-wasilata (seorang perantara - menuju Tuhan) yang lebih tepat adalah Rasul-Nya, Al-Hadi, atau Ahli Zikir, karena istilah-istilah inilah yang terdapat dalam Al-Quran. Tapi metode tafsir maudhu $i$ Al-Qarafi ini hanya bisa digunakan oleh orang-orang yang mengerti bahasa Arab, yang tentunya sulit bagi mahasiswa umum.

Bagaimanakah caranya agar mahasiswa umum dapat juga memahami pokok-pokok agama secara langsung dari Al-Quran? Untuk menjaga kebenaran Al-Quran, ketiga standar Al-Qarafi tersebut tentu harus dipertahankan, tapi dengan cara yang lebih mudah. Bagi mahasiswa umum, ketiga standar tersebut bisa mempercayakan kepada Al-Quran dan Terjemahnya yang diterbitkan Kementerian Agama RI. Dengan bantuan Digital Quran ver 3.1 atau ver 3.2, metode tematik digital Quran lebih mudah diaplikasikan oleh mahasiswa. Metode ini memiliki tiga keunggulan: (1) merupakan tafsir Al-Quran bil-Quran, sehingga lebih aman dari kekeliruan akal-pikiran (Afandi, 2001); (2) dengan bantuan Digital Quran metode ini mudah diaplikasikan; dan (3) karena satu dan dua tersebut, maka slogan agar umat kembali kepada Al-Quran akan lebih mudah terwujud. 


\section{Metode Penelitian}

Penelitian ini dengan hasil uji pengembangan model pembelajaran tematik digital Quran. Oleh karena itu desain penelitian yang paling tepat adalah kuasi eksperimen dan research and development ( $\mathrm{R} \& \mathrm{D})$ yang diadaptasi dari Gall (1983) dan Sugioyono (2017).

Data yang digunakan dalam penelitian ini adalah data hasil uji coba metode tematik digital quran. Teknik analisis menggunakan pendekatan kualitatif. Subyek atau responden penelitian adalah mahasiswa UNISBA dan UPI kemudian diberikan soal berikut: (1) Apa makna beriman dalam Al-Quran? (2) Apa setiap orang Islam otomatis beriman? (3) Apa makna kafir dalam Al-Quran? (4) Apa setiap non Muslim otomatis kafir? Bagaimana keimanan/kekafiran Ahli Kitab menurut Al-Quran, (5) apa mereka semuanya otomatis kafir ataukah ada di antara mereka yang beriman?

\section{Hasil dan Pembahasan}

\section{Desain Model Pembelajaran 'Tematik Digital Qur'ān'}

Desain model pembelajaran "Thematic Digital Quran" dimulai dengan skenario model, dilanjutkan dengan langkah-langkah model, dan terakhir impelementasi model. Penyusunan draft model pembelajaran mengikuti Model's of Teaching dari Joyce \& Weil (2009), Joyce et al (2011), dan Model-model Pengajaran dari Dahlan, Ed. (1990), tapi sudah disederhanakan oleh Rahmat (2015) sehingga lebih mudah diaplikasikan.

\section{Skenario model}

Skenario model dalam setiap tatap mukanya dilakukan dengan tiga tahapan: kegiatan membuka kuliah, kegiatan inti, dan kegiatan menutup kuliah.

Pertama, membuka perkuliahan. Pada tahap ini dosen menjelaskan tema kuliah (misal, memahami makna Ahli Kitab dengan model perkuliahan “Thematic Digital Quran”. Adapun tujuan perkuliahan, agar mahasiswa memahami karakter dan keimanan Ahli Kitab menurut Al-Quran.

Kedua, kegiatan inti. Dosen menyampaikan pesan utama kuliah (misal: memahami karakter dan keimanan Ahli Kitab). Pada tahap ini pertama kali dosen meminta mahasiswa untuk menjelaskan siapa Ahli Kitab itu? Bagaimanakah karakter Ahli Kitab? dan bagaimana pula keimanan Ahli Kitab (berdasarkan pengetahuan siap mereka, bisa dari pengajaran 
agama sebelumnya ataupun dari bacaan-bacaan dan pengajian-pengajian). Kemudian dosen mengajak mahasiswa untuk memahami makna term ini secara langsung dari Al-Quran (dengan model perkuliahan "Tematik Digital Quran"). Dosen kemudian menjelaskan dan melatihkan model perkuliahan ini disertai contoh-contoh implementasinya.

Ketiga, menutup perkuliahan. Pada tahap ini (perkuliahan keempat) dosen meminta mahasiswa mendiskusikan tentang makna Ahli Kitab menurut Al-Quran. Dosen meminta mahasiswa untuk menelaah, apakah pemahaman mereka tentang makna Ahli Kitab yang digali secara langsung dari Al-Quran maknanya sama ataukah berbeda dengan makna Ahli Kitab sebelum mahasiswa menggunakan model perkuliahan yang baru ini.

Langkah belajar (di luar perkuliahan) para mahasiswa secara individual mengadakan bimbingan dengan dosen. Hasil penelitian Rahmat et al. (2017) mahasiswa "kurang" teliti dalam membaca terlebih-lebih dalam mengambil "pesan" ayat dari setiap ayat Al-Quran yang di-copy-nya. Kekeliruan yang paling fatal, mahasiswa sering menarik "pesan" dan "kesimpulan" ayat bukan berdasarkan teks/terjemah ayat Al-Quran, melainkan lebih didasarkan kepada pengetahuan agama yang telah mereka terima. Kekeliruan berikutnya, mahasiswa menarik "pesan" dan "kesimpulan" ayat cenderung ceroboh sehingga menyimpang dari teks/terjemah Al-Quran. Oleh karena itu dosen pun dituntut untuk mengabdi secara sungguh dan tulus, demi mengajarkan pencarian makna agama secara langsung dari sumbernya.

\section{Prinsip Dasar Memaknai Suatu Term Dalam Al-Quran}

Prinsip-prinsip umum yang perlu dipahami bersama oleh dosen dan mahasiswa dalam mengimplementasikan model pembelajaran Tematik Digital Quran adalah: (1) Al-Quran adalah Kitab petunjuk beragama, sehingga istilah-istilah apa saja (terutama istilah-istilah fundamental agama) harus dikaitkan dengan keberagamaan. Contoh term basyar=manusia (sering dimaknai manusia dimensi biologis), al-insan=manusia (sering dimaknai manusia dimensi psikologis-spiritual), dan an-nas=manusia (sering dimaknai manusia dimensi sosiologis) melainkan harus dikaitkan dengan keberagamaan. Misal, term basyar dalam AlQuran digunakan oleh manusia umumnya untuk merendahkan Nabi/Rasul, yakni bahwa Nabi/Rasul itu sama dengan kita, untuk apa kita mentaati Nabi/Rasul? Term al-insan berkaitan dengan keteledoran manusia dalam beragama, bahwa manusia itu zalim, bodoh, tidak mengerti agama yang lurus, dan penantang Rasul; term an-nas berkaitan dengan kecenderungan manusia umumnya untuk beragama dengan mengikuti pola beragama orang 
tua/leluhur atau pola beragama yang dianut oleh mayoritas, tidak mau mengikuti pola beragama Rasul (Rahmat, 2012). (2) Semua term yang sama (misal term Ahli Kitab) harus dianalisis semuanya, jangan sampai ada satu ayat pun yang terlewat.

\section{Tahap-Tahap Pembelajaran}

Dosen dan mahasiswa perlu menyiapkan Digital Quran versi 3.1 (Al-Quran dan Terjemahnya yang diterbitkan Kementerian Agama Republik Indonesia) dan format pembelajaran. Format yang perlu disiapkan berupa tabel dengan 5 kolom, terdiri dari Nomor Urut, Nomor Surah dan Ayat Al-Quran, Teks Al-Quran dan Terjemahnya (boleh terjemahnya saja), Pesan Ayat, dan Kesimpulan Sementara untuk setiap 5-10 ayat (tergantung panjang-pendeknya ayat), seperti dalam tabel berikut.

Tabel 1. Makna Islam

(Berdasarkan Metode Tematik Digital Quran )

\begin{tabular}{|c|c|c|c|c|}
\hline No. & $\begin{array}{c}\text { QS... } \\
\text { ayat... }\end{array}$ & $\begin{array}{c}\text { Teks Al-Quran \& } \\
\text { Terjemahnya }\end{array}$ & Pesan ayat & $\begin{array}{c}\text { Kesimpulan } \\
\text { sementara }\end{array}$ \\
\hline 1 & & & & \\
\hline 2 & & & & \\
\hline$\ldots$ & & & & \\
\hline 10 & & & & \\
\hline
\end{tabular}

Pertama, tentukan tema pembelajaran (sebagai judul tabel/format pembelajaran). Jika term keagamaan yang dikaji term Ahli Kitab, maka tema pembelajarannya adalah "Makna, Karakter, dan Keimanan Ahli Kitab.”

Kedua, Copy-paste Terjemah Al-Quran (dalam kolom 3). Ada tiga langkah untuk mengcopy-paste Terjemah Al-Quran, yakni: (1) hanya mengcopy-paste Terjemah Al-Quran yang sesuai dengan tema pembelajaran; (2) bacalah terjemah ayat, apa sudah dapat menjawab tema pembelajaran? Jika belum maka bacalah satu atau beberapa ayat sebelum dan/atau sesudahnya; dan (3) copy-paste terjemah ayat yang dapat menjawab tema pembelajaran (satu atau beberapa ayat). Setelah itu tuliskan No. Surah dan Ayat (dalam kolom 2) dan No. Urut (dalam kolom 1).

Ketiga, cara menuliskan isi Pesan Ayat (dalam kolom 4). Ada dua ketentuan: (1) buat kalimat yang sederhana, mudah dimengerti, dan benar sesuai terjemah ayat; dan (2) istilahistilah yang digunakan harus sesuai dengan istilah-istilah dalam Terjemah Al-Quran, tidak boleh menyimpang dari isi ayat Al-Quran. 
Keempat, cara merumuskan Kesimpulan Sementara (dalam kolom 5). Ada dua ketentuan: (1) buat kalimat yang lebih sederhana dan lebih mudah dimengerti dibandingkan dengan Pesan ayat. Jika kalimat dalam kolom Pesan Ayat sudah sederhana, mudah dimengerti, dan benar maka tinggal mengcopy-paste saja. Artinya, boleh saja kalimat dalam kolom Kesimpulan Sementara sama persis dengan kalimat dalam kolom Pesan Ayat; dan (2) hanya menuliskan satu rumusan Kesimpulan Sementara dari rumusan-rumusan beberapa Pesan Ayat yang sama. Dengan demikian jumlah rumusan Kesimpulan Sementara bisa lebih sedikit dibandingkan dengan jumlah rumusan Pesan Ayat.

Kelima, cara merumuskan Kesimpulan per-tabel/Format Pembelajaran. Ada dua langkah: (1) mengcopy-paste seluruh Kesimpulan Sementara dalam kolom 5; dan (2) menyusun urutan kesimpulan mulai dari makna yang paling umum hingga lebih khusus (Jadi, urutan kesimpulan tidak harus mengikuti Nomor urut Surah dan ayat).

Keenam, cara merumuskan Kesimpulan (akhir) dari seluruh tabel/Format Pembelajaran. Ada empat langkah: (1) Copy-paste seluruh kesimpulan dari setiap tabel/format pembelajaran; (2) Hapus kesimpulan-kesimpulan yang sama dari setiap tabel/format pembelajaran; (3) Susun kembali kalimat-kalimat dari setiap kesimpulan agar dapat dengan jelas menjawab makna-makna keagamaan yang dicari; dan (4) Susun kembali urutan kesimpulan mulai dari makna yang paling umum hingga lebih khusus (Jadi tidak harus berdasarkan Nomor urut Surah dan ayat), jika sebuah term keagamaan dalam Al-Quran terdiri dari 20 ayat atau lebih maka perlu dibuat beberapa tabel. Term Ahli Kitab, misalnya saja sekitar 31 term/ayat, maka perlu dibuat sekitar 3-4 tabel. Setelah semua term dianalisis kemudian bisa diambil kesimpulan tentang makna sebuah term. Makna Ahli Kitab hanya bisa disimpulkan setelah semua term/ayat tentang Ahli Kitab (sekitar 31 term/ayat) dianalisis semuanya.

\section{Langkah-Langkah Teknis Pembelajaran}

Adapun langkah-langkah teknis aplikasi digital Quran ke dalam tabel/format pembelajaran sebagai berikut: (1) Klik folder Digital Quran versi 3.1 (2) Klik file (gambar daun sirih warna Hijau) dan (3) Cari term (kata) yang diinginkan ada pilihan Bahasa Indonesia (huruf Latin) dan Bahasa Arab (huruf Arab). Misal term Ahli Kitab. Caranya: Klik cari (Ind/Eng), kemudian tulis kata Ahli Kitab. Nanti akan muncul di layar (bawah) term Ahli Kitab= 35 items. Maksudnya, jumlah term/kata Ahli Kitab sebanyak 35 kata, mungkin dalam 35 ayat atau kurang. Jika menggunakan Bahasa Arab, klik cari (Arab), 
kemudian klik huruf alif ('), ha (ه), lam (১), kemudian klik spasi, kemudian klik lagi huruf kaf(ك), ta (ت), alif('), dan ba (ب) maka akan muncul di layar (bawah) Ahli Kitab= 31 items. Maksudnya, jumlah term/kata Ahli Kitab sebanyak 31 kata dalam 31 ayat atau kurang. Jumlah term Ahli Kitab dalam Bahasa Indonesia lebih banyak karena merupakan terjemahan langsung dari term Ahli Kitab, ditambah dengan term yang bermakna Ahli Kitab, yang terjemahannya biasanya diberi tanda kurung (Ahli Kitab). (4) Klik copy Teks Al-Quran dan Terjemahnya (boleh terjemahnya saja) dari Digital Quran, kemudian klik paste dalam format/tabel kolom ketiga Teks Al-Quran \& Terjemahnya. Sebelumnya tuliskan nomor urut dan nama surah serta nomor ayat (pada kolom 1 dan 2). (5) Tuliskan pesan ayat dalam kolom keempat Pesan Ayat berdasarkan makna dari Al-Quran dan Terjemahnya, teks Ayat, misalnya, wa inna min ahlil Kitabi laman yu`minu billahi... =dan di antara Ahli Kitab ada orang yang beriman kepada Allah... (QS 3/Ali Imran: 199). Kemudian dalam kolom Pesan Ayat tulislah “di antara Ahli Kitab itu ada orang yang beriman kepada Allah....”. (6) Tuliskan kesimpulan sementara pada kolom kelima Kesimpulan Sementara berdasarkan Pesan ayat (kolom keempat). Contoh kesimpulan sementara dari QS 3/Ali Imran ayat 199 tersebut: "Sebagian Ahli Kitab ada orang yang beriman kepada Allah".

\section{Implementasi Model Pembelajaran 'Tematik Digital Qur'ān'}

Pertama kali dosen mendemonstrasikan penggunaan metode Tematik Digital Quran dengan menggunakan Infocus. Kemudian dosen mengaplikasikannya untuk mengkaji suatu term keagamaan. Misal, term Ahli Kitab. Masalah yang ingin dikajinya, siapakah Ahli Kitab itu? Bagaimanakah karakter Ahli Kitab? Dan bagaimanakah keimanan Ahli Kitab, perspektif Al-Quran? Diskusikanlah dengan teman-teman atau dalam diri Anda sendiri, mengapa ada ayat tentang Ahli Kitab, di samping ada ayat tentang orang-orang beriman dan orang-orang kafir? Dengan menggunakan metode Tematik Digital Quran, jawaban mahasiswa umumnya sudah mendekati kebenaran. Para mahasiswa akhirnya akan mengetahui makna Ahli Kitab dan makna keagamaan lainnya dengan relatif benar (berdasarkan Al-Quran).

Setelah mempersiapkan Digital Quran versi 3.1 dan format (tabel) pembelajaran, mahasiswa menuliskan "Ahli Kitab” dalam kolom cari [ind/eng], kemudian klik OK, maka akan muncul di layar (bawah-kiri) Found 35 items. Maksudnya, term Ahli Kitab dalam AlQuran ada 35 term/kata dalam puluhan ayat Al-Quran. Kemudian mahasiswa melakukan langkah-langkah belajar berikut: Langkah pertama, klik 2:105 di sebelah kiri tabel di atas. Maksudnya QS 2/Al-Baqarah ayat 105 (=Al-Quran, surah kedua - surah Al-Baqarah, ayat 
105), maka akan muncul di layar teks ayat dan terjemahnya dari QS 2:105 tersebut. Jika list pada layar ayat-ayatnya berurutan maka copy dalam satu baris.

Langkah kedua, copy ayat tersebut, kemudian paste ke dalam kolom 3 tabel pembelajaran. Demikianlah seterusnya hingga semua ayat tentang Ahli Kitab di-copy-paste semuanya. Misal, teks/terjemah QS 3/Ali Imran ayat 199: Dan sesungguhnya di antara Ahli Kitab ada orang yang beriman kepada Allah dan kepada apa yang diturunkan kepada kamu dan yang diturunkan kepada mereka sedang mereka berendah hati kepada Allah dan mereka tidak menukarkan ayat-ayat Allah dengan harga yang sedikit. Mereka memperoleh pahala di sisi Tuhan-nya. Sesungguhnya Allah amat cepat perhitungan-Nya (Digital Quran ver 3.1., 2013).

Langkah ketiga, tuliskan pesan ayat. Pesan ayat diambil dari teks/terjemah Al-Quran. Syarat menuliskan pesan ayat: (1) harus benar, maksudnya harus sesuai dengan isi teks/terjemah Al-Quran, (2) harus lebih mudah dipahami dibanding dengan terjemah ayat, dan (3) harus disusun dalam kelimat yang sederhana. Pesan ayat yang harus dituliskan dari QS 3/Ali Imran ayat 199 (di langkah kedua): "Di antara Ahli Kitab ada orang yang beriman kepada Allah. Mereka rendah hati kepada Allah, dan mereka tidak menukar ayat-ayat Allah dengan harga yang murah. Mereka mendapat pahala dari Allah.”

Langkah keempat, tuliskan kesimpulan sementara. Kesimpulan (sementara) ini diambil dari pesan ayat. Cara menyusunnya harus lebih jelas dan lebih sederhana dibanding pesan ayat. Jika pesan ayat sudah jelas dan sederhana maka isi kesimpulan sementara bisa sama dengan pesan ayat (di-copy paste). Kesimpulan sementara dari QS 3/Ali Imran ayat 199 (di langkah ketiga): "Di antara Ahli Kitab ada orang yang beriman kepada Allah. Mereka rendah hati kepada Allah, dan mereka tidak menukar ayat-ayat Allah dengan harga yang murah. Mereka mendapat pahala dari Allah", sama dengan pesan ayat karena sudah jelas dan sederhana.

Langkah kelima, setelah semua ayat Al-Quran yang menguraikan Ahli Kitab dibahas semuanya, maka langkah terakhir adalah membuat kesimpulan sesuai pertanyaan di awal pembelajaran: siapakah Ahli Kitab itu? Bagaimanakah karakter Ahli Kitab itu, apakah mereka baik atau buruk? Dan bagaimanakah keimanan Ahli Kitab itu, apakah ada di antara mereka yang beriman ataukah semuanya kafir?

Dengan bantuan format/tabel pembelajaran, hasil kajian mahasiswa terhadap term Ahli Kitab seperti contoh berikut. 
TABEL 2

MAKNA, KARAKTER, DAN KEIMANAN AHLI KITAB DALAM AL-QURAN

(Berdasarkan Metode Tematik Digital Quran )

\begin{tabular}{|c|c|c|c|c|}
\hline No. & $\begin{array}{l}\text { QS... } \\
\text { ayat... }\end{array}$ & $\begin{array}{c}\text { Teks Al-Quran/ } \\
\text { Terjemahnya }\end{array}$ & Pesan ayat & $\begin{array}{l}\text { Kesimpulan } \\
\text { sementara }\end{array}$ \\
\hline 1 & $2: 105$ & $\begin{array}{lrr}\text { Orang-orang kafir dari } & \text { Ahli } \\
\text { Kitab dan orang-orang musyrik } \\
\text { tiadarangang } \\
\text { diturunkannya menginginkan } \\
\text { kebaikan kepadamu } & \text { sesuatu } \\
\text { Tuhanmu; dan } & \text { Allah } \\
\text { menentukan siapa } & \text { yang } \\
\text { dikehendaki-Nya } & \text { (untuk } \\
\text { memperoleh) rahmat-Nya; dan } & \text { Allah mempunyai karunia yang } \\
\text { besar. }\end{array}$ & $\begin{array}{l}\text { Orang-orang kafir } \\
\text { dari kalangan Ahli } \\
\text { Kitab tidak } \\
\text { menginginkan } \\
\text { diturunkannya } \\
\text { sesuatu kebaikan } \\
\text { kepada orang- } \\
\text { orang beriman. }\end{array}$ & $\begin{array}{l}\text { Ahli Kitab yang } \\
\text { kafir tidak } \\
\text { menginginkan } \\
\text { diturunkannya } \\
\text { sesuatu } \\
\text { kebaikan kepada } \\
\text { orang-orang } \\
\text { beriman. }\end{array}$ \\
\hline 2 & $\begin{array}{c}3: \\
70-71\end{array}$ & $\begin{array}{l}\text { Hai Ahli Kitab, mengapa kamu } \\
\text { mengingkari ayat-ayat Allah, } \\
\text { padahal kamu mengetahui. } \\
\text { Hai Ahli Kitab, mengapa kamu } \\
\text { mencampur-adukkan yang haq } \\
\text { dengan yang bathil, dan } \\
\text { menyembunyikan kebenaran, } \\
\text { padahal kamu mengetahuinya? }\end{array}$ & $\begin{array}{l}\text { Tuhan memper- } \\
\text { tanyakan mengapa } \\
\text { Ahli Kitab meng- } \\
\text { ingkari ayat-ayat } \\
\text { Allah, mencampur- } \\
\text { adukkan yang hak } \\
\text { dan yang batil, dan } \\
\text { menyembunyikan } \\
\text { kebenaran }\end{array}$ & $\begin{array}{l}\text { Ahli Kitab } \\
\text { divonis kafir jika } \\
\text { mereka } \\
\text { mengingkari } \\
\text { ayat-ayat Allah, } \\
\text { mencampur- } \\
\text { adukkan yang } \\
\text { hak dan yang } \\
\text { batil, dan } \\
\text { menyembunyikan } \\
\text { kebenaran }\end{array}$ \\
\hline 3 & $3: 75$ & $\begin{array}{lr}\text { Di antara Ahli Kitab ada orang } \\
\text { yang jika } & \text { kamu } \\
\text { mempercayakan } & \text { kepadanya } \\
\text { harta yang } & \text { banyak, } \\
\text { dikembalikannya } & \text { kepadamu; } \\
\text { dan di antara mereka ada orang } \\
\text { yang jika r kamu } \\
\text { mempercayakan kepadanya } \\
\text { satu dinar (saja), tidak } \\
\text { dikembalikannya kepadamu } \\
\text { kecuali jika kamu selalu } \\
\text { menagihnya. Yang demikian itu } \\
\text { lantaran mereka mengatakan: } \\
\text { "Tidak ada dosa bagi kami } \\
\text { terhadap orang-orang ummi." } \\
\text { Mereka berkata dusta terhadap } \\
\text { Allah, padahal } \\
\text { mengetahui. }\end{array}$ & $\begin{array}{l}\text { Di antara Ahli } \\
\text { Kitab ada yang } \\
\text { amanah dan ada } \\
\text { yang khianat }\end{array}$ & $\begin{array}{l}\text { Di antara Ahli } \\
\text { Kitab ada yang } \\
\text { amanah dan ada } \\
\text { yang khianat }\end{array}$ \\
\hline 4 & $3: 113$ & $\begin{array}{l}\text { Mereka itu tidak sama; di antara } \\
\text { Ahli Kitab itu ada golongan } \\
\text { yang berlaku lurus; mereka }\end{array}$ & $\begin{array}{l}\text { Di antara Ahli Kitab } \\
\text { ada yang berlaku } \\
\text { lurus. Mereka }\end{array}$ & $\begin{array}{l}\text { Di antara Ahli } \\
\text { Kitab ada yang } \\
\text { berlaku lurus. }\end{array}$ \\
\hline
\end{tabular}


M. Wildan bin H,M. Yahya, Munawar Rahmat, ... Perubahan Pemahaman Mahasiswa ...

\begin{tabular}{|c|c|c|c|c|}
\hline & & $\begin{array}{l}\text { membaca ayat-ayat Allah pada } \\
\text { beberapa waktu di malam hari, } \\
\text { sedang mereka juga bersujud. }\end{array}$ & $\begin{array}{l}\text { membaca ayat-ayat } \\
\text { Allah pada sebagian } \\
\text { malam, dan mereka } \\
\text { pun bersujud. }\end{array}$ & $\begin{array}{l}\text { Mereka membaca } \\
\text { ayat-ayat Allah } \\
\text { pada sebagian } \\
\text { malam, dan } \\
\text { mereka pun } \\
\text { bersujud. }\end{array}$ \\
\hline 5 & $3: 199$ & $\begin{array}{l}\text { dan sesungguhnya di antara } \\
\text { Ahli Kitab ada orang yang } \\
\text { beriman kepada Allah dan } \\
\text { kepada apa yang diturunkan } \\
\text { kepada kamu dan yang } \\
\text { diturunkan kepada mereka } \\
\text { sedang mereka berendah hati } \\
\text { kepada Allah dan mereka tidak } \\
\text { menukarkan ayat-ayat Allah } \\
\text { dengan harga yang sedikit. } \\
\text { Mereka memperoleh pahala di } \\
\text { sisi Tuhannya. Sesungguhnya } \\
\text { Allah amat cepat perhitungan- } \\
\text { Nya. }\end{array}$ & $\begin{array}{l}\text { Di antara Ahli Kitab } \\
\text { ada yang beriman } \\
\text { kepada Allah. } \\
\text { Mereka rendah hati } \\
\text { kepada Allah, dan } \\
\text { mereka tidak } \\
\text { menukar ayat-ayat } \\
\text { Allah dengan harga } \\
\text { yang murah. Mereka } \\
\text { mendapat pahala } \\
\text { dari Allah. }\end{array}$ & $\begin{array}{l}\text { Di antara Ahli } \\
\text { Kitab ada yang } \\
\text { beriman kepada } \\
\text { Allah. Mereka } \\
\text { rendah hati } \\
\text { kepada Allah, } \\
\text { dan mereka tidak } \\
\text { menukar ayat- } \\
\text { ayat Allah } \\
\text { dengan harga } \\
\text { yang murah. } \\
\text { Mereka mendapat } \\
\text { pahala dari Allah. }\end{array}$ \\
\hline 6 & $5: 15$ & $\begin{array}{l}\text { Hai Ahli Kitab, sesungguhnya } \\
\text { telah datang kepadamu Rasul } \\
\text { Kami, menjelaskan kepadamu } \\
\text { banyak dari isi } A l \text {-Kitab yang } \\
\text { kamu sembunyikan dan banyak } \\
\text { (pula yang kamu) dibiarkannya. } \\
\text { Sesungguhnya telah datang } \\
\text { kepadamu cahaya dari Allah } \\
\text { dan Kitab yang menerangkan. }\end{array}$ & $\begin{array}{l}\text { Kepada Ahli Kitab } \\
\text { (yang kafir) Tuhan } \\
\text { menegaskan bahwa } \\
\text { telah datang seorang } \\
\text { Rasul yang dapat } \\
\text { menjelaskan isi } \\
\text { Kitab yang mereka } \\
\text { sem-bunyikan dan } \\
\text { isi Kitab yang } \\
\text { mereka biarkan } \\
\text { (karena tidak } \\
\text { dipahami atau tidak } \\
\text { dijadikan rujukan) }\end{array}$ & $\begin{array}{l}\text { Ahli Kitab (yang } \\
\text { kafir) cenderung } \\
\text { menyembunyikan } \\
\text { dan membiarkan } \\
\text { isi Kitab (karena } \\
\text { tidak paham atau } \\
\text { tidak dijadikan } \\
\text { rujukan). Jika } \\
\text { mereka ingin } \\
\text { memahami isi } \\
\text { Kitab secara } \\
\text { utuh, maka } \\
\text { mereka harus } \\
\text { beriman kepada } \\
\text { Rasul (karena } \\
\text { dialah yang dapat } \\
\text { menjelaskan } \\
\text { seluruh isi Kitab) }\end{array}$ \\
\hline 7 & $\begin{array}{c}5: \\
65-66\end{array}$ & $\begin{array}{l}\text { Dan sekiranya Ahli Kitab } \\
\text { beriman dan bertakwa, tentulah } \\
\text { Kami tutup (hapus) kesalahan- } \\
\text { kesalahan mereka dan tentulah } \\
\text { Kami masukkan mereka ke } \\
\text { dalam surga yang penuh } \\
\text { kenikmatan. } \\
\text { Dan sekiranya mereka } \\
\text { sungguh-sungguh menjalankan } \\
\text { (hukum) Taurat, Injil dan (Al } \\
\text { Qur'an) yang diturunkan kepada } \\
\text { mereka dari Tuhannya, niscaya } \\
\text { mereka akan mendapat }\end{array}$ & $\begin{array}{l}\text { 1. Sekiranya Ahli } \\
\text { Kitab beriman } \\
\text { dan bertakwa, } \\
\text { Allah akan } \\
\text { menghapus } \\
\text { seluruh } \\
\text { kesalahannya dan } \\
\text { memasuk-kannya } \\
\text { ke surga. } \\
\text { 2. Sekiranya } \\
\text { mereka sungguh- } \\
\text { sungguh } \\
\text { menjalankan }\end{array}$ & $\begin{array}{l}\text { Ahli Kitab dinilai } \\
\text { beriman dan } \\
\text { bertakwa jika } \\
\text { mereka } \\
\text { menjalankan } \\
\text { Kitab Suci } \\
\text { dengan sungguh- } \\
\text { sungguh (Orang } \\
\text { Yahudi } \\
\text { menjalankan } \\
\text { Taurat dengan } \\
\text { sungguh- } \\
\text { sungguh, orang }\end{array}$ \\
\hline
\end{tabular}




\begin{tabular}{|c|c|c|c|c|}
\hline & & $\begin{array}{l}\text { makanan dari atas mereka dan } \\
\text { dari bawah kaki mereka. Di } \\
\text { antara mereka ada golongan } \\
\text { yang pertengahan. Dan } \\
\text { alangkah buruknya apa yang } \\
\text { dikerjakan oleh kebanyakan } \\
\text { mereka. }\end{array}$ & $\begin{array}{l}\text { Taurat, Injil, atau } \\
\text { Al-Quran, maka } \\
\text { mereka akan } \\
\text { memperoleh } \\
\text { pahala. }\end{array}$ & $\begin{array}{l}\text { Nasrani } \\
\text { menjalankan Injil } \\
\text { dengan sungguh- } \\
\text { sungguh, dan } \\
\text { orang Islam } \\
\text { menjalankan Al- } \\
\text { Quran dengan } \\
\text { sungguh- } \\
\text { sungguh) }\end{array}$ \\
\hline 8 & $5: 68$ & $\begin{array}{l}\text { Katakanlah: "Hai Ahli Kitab, } \\
\text { kamu tidak dipandang } \\
\text { beragama sedikitpun hingga } \\
\text { kamu menegakkan ajaran- } \\
\text { ajaran Taurat, Injil, dan Al- } \\
\text { Quran yang diturunkan } \\
\text { kepadamu dari Tuhanmu". } \\
\text { Sesungguhnya apa yang } \\
\text { diturunkan kepadamu (Nabi } \\
\text { Muhammad SAW) dari } \\
\text { Tuhanmu akan menambah } \\
\text { kedurhakaan dan kekafiran } \\
\text { kepada kebanyakan dari } \\
\text { mereka; maka janganlah kamu } \\
\text { bersedih hati terhadap orang- } \\
\text { orang yang kafir itu. }\end{array}$ & $\begin{array}{l}\text { Ahli Kitab dinilai } \\
\text { Tuhan tidak } \\
\text { beragama, kecuali } \\
\text { jika mereka } \\
\text { menegakkan } \\
\text { ajaran-ajaran } \\
\text { Taurat, Injil, dan } \\
\text { Al-Quran }\end{array}$ & $\begin{array}{l}\text { Ahli Kitab } \\
\text { dinilai Tuhan } \\
\text { beragama yang } \\
\text { benar, jika } \\
\text { mereka } \\
\text { menegak-kan } \\
\text { ajaran-ajaran } \\
\text { Taurat, Injil, dan } \\
\text { Al-Quran } \\
\text { (Orang Yahudi } \\
\text { menjalankan } \\
\text { Taurat dengan } \\
\text { sungguh- } \\
\text { sungguh, orang } \\
\text { Nasrani } \\
\text { menjalankan } \\
\text { Injil dengan } \\
\text { sungguh- } \\
\text { sungguh, dan } \\
\text { orang Islam } \\
\text { menjalankan Al- } \\
\text { Quran dengan } \\
\text { sungguh- } \\
\text { sungguh) }\end{array}$ \\
\hline
\end{tabular}

Dengan mengkaji ayat-ayat Al-Quran tentang makna, keimanan, dan karakter Ahli Kitab dengan bantuan tabel/format pembelajaran (sebagaimana dalam tabel 2) para mahasiswa dengan bimbingan dosen dapat menyimpulkannya sebagai berikut:

Ahli Kitab merujuk kepada orang-orang yang beragama dengan mengikuti petunjuk Kitab Suci peninggalan Nabi/Rasul terdahulu (QS 5/Al-Maidah: 15). Kalam Tuhan dalam ayat ini menegaskan bahwa telah datang seorang Rasul yang menjelaskan dengan benar isi Kitab Suci yang disembunyikan dan yang dibiarkan (tidak dijadikan rujukan) oleh mereka. Pada saat Nabi Muhammad hadir di tengah-tengah umat (tahun 622-632 Masehi) di Madinah banyak penganut agama Yahudi dan Nasrani. Oleh karena itu beliau menyebut mereka sebagai Ahli Kitab, karena mereka beragama dengan bersandar kepada Kitab Suci yang telah 
diturunkan kepada Nabi/Rasul terdahulu, tidak bersandar kepada Nabi Muhammad sebagai Rasul yang hadir saat itu (sebagai pengganti Rasul sebelumnya).

Ahli Kitab ada yang beriman. Orang Yahudi dan Nasrani akan dihapuskan segala dosa dan salahnya serta dimasukkan ke dalam surga, asalkan mereka beriman dan bertakwa (QS 5/Al-Maidah ayat 65). Janji Tuhan ini diperkuat dengan ayat berikutnya yang menyebutkan, sekiranya orang Yahudi sungguh-sungguh menjalankan Taurat dan orang Nasrani sungguhsungguh menjalankan Injil, begitu juga menjalankan apa yang diturunkan kepada mereka dari Tuhannya, niscaya mereka memperoleh kenikmatan yang melimpah dari Tuhan (QS 5/Al-Maidah ayat 66).Ungkapan "sekiranya" dalam kedua ayat tersebut menunjukkan bahwa ada di antara Ahli Kitab itu yang dinilai beriman dan beramal saleh oleh Tuhan akan dimasukkan ke dalam surga-Nya. Hal ini ditegaskan dalam QS 3/Ali Imran ayat 199: “dan sesungguhnya di antara Ahli Kitab ada orang yang beriman kepada Allah dan kepada apa yang diturunkan kepada kamu dan yang diturunkan kepada mereka, sedang mereka berendah hati kepada Allah, dan mereka tidak menukarkan ayat-ayat Allah dengan harga yang sedikit. Mereka memperoleh pahala di sisi Tuhannya. Sesungguhnya Allah amat cepat perhitunganNya” (Digital Quran ver 3.1., 2013). Masih dalam QS 3/Ali Imran ayat 199 tersebut, Karakter Ahli Kitab yang beriman dalam ayat di atas memiliki sifat-sifat: (1) tunduk merendahkan diri kepada Allah, (2) tidak ada rasa sombong sedikit pun; dan Kemudian mereka (3) tidak menukarkan ayat-ayat Allah dengan harga yang sedikit. Maksudnya, mereka tidak menjadikan ayat-ayat Allah untuk kepentingan bisnisnya, melainkan untuk menjalankan keimanan, peribadatan, dan amal saleh.

Kebanyakan Ahli Kitab adalah kafir (QS 2/Al-Baqarah: 105, 109, QS 3/Ali Imran: 7071, dan QS 5/Al-Maidah ayat 15). Ayat-ayat ini memperkuat ayat-ayat sebelumnya, bahwa tidak semua Ahli Kitab kafir. Bahwa di antara Ahli Kitab ada yang beriman. Adapun penyebab Ahli Kitab divonis kafir oleh Tuhan karena: Pertama, mengingkari ayat-ayat Allah, mencampur-adukkan yang hak dan yang batil, menyembunyikan kebenaran, dan menyembunyikan ayat-ayat Tuhan (Q 3/Ali Imran: 70-71); kedua, cenderung menyembunyikan dan membiarkan isi Kitab - yakni tidak menjadikannya sebagai rujukan (Q 5/Al-Maidah: 15); ketiga, tidak menginginkan diturunkannya sesuatu kebaikan kepada orang-orang beriman (Q 2/Al-Baqarah: 105); dan keempat, menginginkan agar orang-orang beriman kembali kafir (Q 2/Al-Baqarah: 109). 
Ahli Kitab ada yang berkarakter amanah (jujur), sehingga orang-orang beriman bisa menitipkan amanah itu kepadanya. Tapi di antara mereka ada yang kurang jujur. FirmanNya dalam QS 3/Ali Imran ayat 75: Ahli Kitab adalah orang yang jika kamu mempercayakan kepadanya harta yang banyak, dikembalikannya kepadamu; dan di antara mereka ada orang yang jika kamu mempercayakan kepadanya satu Dinar, tidak dikembalikannya padamu, kecuali jika kamu selalu menagihnya. Yang demikian itu lantaran mereka mengatakan: "Tidak ada dosa bagi kami terhadap orang-orang umi. Mereka berkata dusta terhadap Allah, padahal mereka mengetahui (Digital Quran ver 3.1., 2013).

Berdasar hasil pembelajaran tentang makna keimanan dan lainnya, maka dapat dinyatakan bahawa metode Tematik Digital Quran memudahkan mahasiswa memperoleh pemahaman makna, keimanan, dan karakter Ahli Kitab secara lebih tepat. Berbeda dengan model pembelajaran konvensional (kuliah berbasis google dan media sosial lainnya), para mahasiswanya sama sekali tidak memahami makna, karakter, dan keimanan Ahli Kitab dengan benar. Mahasiswa hanya mendasarkan pandangannya kepada umum (para juru dakwah dan media sosial) yang menyebutkan bahwa Ahli Kitab itu kafir. Pandangan seperti ini tentu keliru dan harus diluruskan.

Hasil uji coba model pembelajaran ‘Thematic Digital Quran’ yang diimplementasikan merubah pola pikir mahasiswa tentang makna dan karakter ahli kitab yang dipresentasikan di kelas, adapun pemahaman mahasiswa setelah mempelajari makna keimanan ahli kitab dengan metode tematik digital quran secara ringkas sebagai berikut:

1. Ahli Kitab merujuk kepada orang-orang yang beragama dengan mengikuti Rasul terdahulu, misalnya penganut agama Yahudi dan Nasrani. Karena itu mereka beragama dengan bersandar kepada Kitab Suci yang telah diturunkan kepada Rasul mereka (QS 5/al-Maidah ayat 15).

2. Di antara Ahli Kitab ada yang berkarakter baik, yakni rendah hati (tidak sombong) dan amanah (jujur). Tapi di antara mereka ada yang berkarakter buruk, yakni mengingkari ayat-ayat Allah, suka mencampur-adukkan yang hak dan yang batil, menyembunyikan kebenaran, dan khianat (QS 3/Ali Imran ayat 71, 75, 199, QS 4/al-Nisa ayat 123).

3. Di antara Ahli Kitab ada yang beriman kepada Allah, berlaku lurus, rendah hati (tidak sombong), membaca ayat-ayat Allah pada sebagian malam, dan bersujud (tunduk-patuh kepada Allah) (QS 3/Ali Imran ayat 113 dan 199). Tapi kebanyakan Ahli Kitab adalah kafir (QS 2/al-Baqarah ayat 105 dan 109, QS 3/Ali Imran ayat 70-71, dan QS 5/al-Maidah ayat 15$)$. 


\section{Pembahasan}

Model pembelajaran Tematik Digital Quran terbukti mudah diaplikasikan oleh dosen agama dan mahasiswa umum. Hasil uji coba model menunjukkan, mahasiswa yang belajar agama dengan model Tematik Digital Quran, mereka memahami makna, karakter, dan keimanan Ahli Kitab dengan lebih tepat; sedangkan mahasiswa yang belajar agama dengan metode konvensional tidak memahami makna, karakter, dan keimanan Ahli Kitab dengan tepat.

Indikator model pembelajaran Tematik Digital Quran terbukti efektif dalam meningkatkan pemahaman mahasiswa terhadap ajaran pokok/fundamental agama Islam adalah sebagai berikut: Pertama Mahasiswa dapat memahami makna-makna keagamaan secara langsung dari Al-Quran dengan lebih mudah dan cepat. Kedua mahasiswa tampak puas karena bisa menemukan makna keagamaan secara langsung dari sumbernya. Ketiga mahasiswa lebih puas lagi karena bisa mengamalkan ajaran agama berdasarkan kajian langsung terhadap seluruh ayat Al-Quran dari suatu term keagamaan. Keempat model pembelajaran Digital Quran saat ini memang sangat benar-benar dirasakan manfaatnya, karena dalam waktu relatif cepat para mahasiswa dapat memahami makna-makna keagamaan secara langsung dari Al-Quran. (Rahmat, Munawar \& Fahrudin, 2016) Kelima pemahaman mahasiswa sebelum menggunakan model pembelajaran digital quran tematik mahasiswa cenderung menyebut orang-orang yang beragama selain Islam sebagai orangorang kafir. Tapi setelah menggunakan model pembelajaran yang baru ini mahasiswa tidak lagi men-generalisasikan penganut agama lain sebagai orang-orang kafir. Mahasiswa lebih objektif dan terbuka serta dapat memahami makna sebuah term keagamaan dengan lebih tepat. Tentang term Ahli Kitab, misalnya saja, mahasiswa mengatakan sebagian besar mereka kafir, tapi ada juga di antara mereka yang beriman; padahal sebelum pembelajaran mereka mengatakan semua Ahli Kitab sebagai orang-orang kafir.

Impilikasi dari perubahan pola pikir mahasiswa tentang makna keimanan ahli kitab:

Pertama, Ahli Kitab mencakup juga orang Islam yang hanya menyandarkan agamanya kepada Al-Quran tanpa petunjuk dari Nabi Muhammad. Makna ini tersirat dari QS 5/Al-Maidah ayat 68 dalam kalimat "wamà unzila ilaikum min rabbikum" (and all the revelation that has come to you from your Lord). Kementerian Agama Republik Indonesia menterjemahkannya dengan “dan Al-Quran yang diturunkan kepadamu” (Digital Quran ver 3.1, 2013). Temuan ini tentu berbeda dengan pendapat para ahli tafsir yang membatasi Ahli 
Kitab dengan Yahudi dan Nasrani saja, antara lain dalam Ibn Katsir (Alu Syaikh, 2009), Ath-Thabari (2007), al-Qurthubi (2007), dan Thabathaba`i (2010). Berbeda juga dengan para cendekiawan seperti Nurcholis Madjid (1992) yang memaknainya semua penganut agama di luar Islam yang memiliki Kitab Suci (Yahudi, Nasrani, Hindu, Buddha, Konghucu, dll). Berdasarkan hadits, seorang muslim seharusnya memahami ajaran Islam dari Nabi atau alkhulafaur rāshidīn al-mahdiyyīn (Ad-Darimi, 2013), yakni para wakil/pelanjut Nabi, atau Ulama pewaris Nabi (Ad-Darimi, 2013).

Kedua, di antara Ahli Kitab ada yang beriman (QS 3/Ali Imran ayat 199; QS 5/AlMaidah ayat 65-66). Temuan ini sejalan dengan Muthahhari (2009) yang menyebutkan adanya orang-orang non muslim yang beriman dan beramal saleh, atau dalam buku lainnya disebut muslim fitri, yakni mereka yang beragama non Islam tapi sikap dan perilakunya Islami (Muthahhari, 2007). Sejalan juga dengan Madjid (1992), karenanya mereka berhak atas surga (Maria Ulfa, 2013). Muṭahhari memberi contoh Descartes ((Muthahhari, 2009) dan Harun Nasution (2006) menyebut Bunda Theresia sebagai ahli surga.

Ketiga, di antara Ahli Kitab ada yang berkarakter amanah (jujur), sehingga orangorang beriman bisa menitipkan amanah itu kepadanya. Atas dasar ini maka seorang Ahli Kitab yang jujur dapat diangkat sebagai pemimpin (seperti bupati, wali kota, atau gubernur). Ketika gubernur petahana DKI Jakarta (Indonesia) Basuki Cahya Purnama (keturunan Tionghoa yang beragama Kristen) mengutip satu ayat Al-Quran yang menyinggung kaum muslimin yang fanatik, banyak ulama dan cendekiawan muslim yang membelanya. Tidak kurang dari Kyai Prof. Dr. Said Agil Siradj (Ketua Umum PBNU), Buya Prof. Dr. Syafi'i Maarif (mantan Ketua Umum PP Muhammadiyah), Prof. Dr. Sumanto Al-Qurthubi, Prof. Dr. Nadirsyah Hosen, dan tokoh muda Nusron Wahid (keponakan Mantan Presiden Kyai Abdurrahman Wahid) membela Gubernur Basuki, karena dia seorang gubernur yang baik dan jujur.

Keempat, banyaknya Ahli Kitab yang kafir bukan karena mereka Ahli Kitab, melainkan karena mereka memiliki karakter buruk, yakni: mengingkari ayat-ayat Tuhan, mencampur-adukkan yang hak dan yang batil, menyembunyikan kebenaran, menyembunyikan ayat-ayat Tuhan, membiarkan isi Kitab (tidak dijadikan rujukan), iri dengan diturunkannya sesuatu kebaikan kepada orang-orang beriman, dan menginginkan agar orang-orang beriman kembali kafir. Temuan ini tidak sejalan dengan kebanyakan ulama tafsir seperti Ibn Katsir (Katsir, 1987; Alu Syaikh, 2009), Ath-Thabari (2007) dan alQurthubi (2007). 
Akan tetapi sejalan dengan ulama dan cendekiawan semacan Muṭahhari (Muthahhari, 2007, 2009; Nasution, 2006; Madjid, 1992).

\section{Penutup}

Model pembelajaran Tematik Digital Quran terbukti efektif dalam meningkatkan pemahaman mahasiswa terhadap makna dasar-dasar agama Islam. Mahasiswa terbukti dapat memahami makna istilah-istilah keagamaan secara lebih tepat dibandingkan dengan mahasiswa yang belajar agama dengan metode konvensional.

Adapun secara rinci, kesimpulan dari penelitian ini sebagai berikut. Pertama, ada empat langkah pembelajaran metode Tematik Digital Quran, yakni: (1) tentukan tema kuliah (dasar-dasar agama, seperti makna beriman kepada Rasul, keimanan/kekafiran Ahli Kitab, dan ketentuan shalat); (2) ungkapkan masalah yang ingin diketahui, misalnya memahami makna, karakter, dan keimanan Ahli Kitab; (3) kaji semua ayat Al-Quran tentang suatu term dengan bantuan format pembelajaran. Ada dua tahap untuk melakukan langkah ketiga ini: (a) gunakan Digital Quran versi 3.1, dan (b) gunakan format pembelajaran berupa tabel lima kolom untuk setiap 8-10 ayat; dan (4) tarik kesimpulan akhir yang diambil dari intisari seluruh kesimpulan sementara.

Kedua, model pembelajaran Tematik Digital Quran terbukti efektif dalam meningkatkan pemahaman mahasiswa terhadap ajaran fundamental agama Islam. Dengan tema pembelajaran Ahli Kitab dalam Al-Quran, para mahasiswa memahami bahwa Ahli Kitab itu adalah penganut agama yang bersandarkan kepada Kitab Suci peninggalan Nabi/Rasul terdahulu. Ahli Kitab di zaman Nabi Muhammad adalah penganut agama Yahudi dan Nasrani. Tapi sebenarnya, Ahli Kitab adalah penganut agama-agama (Yahudi, Kristen, Hindu, Buddha, Konghucu, dll). Karakter dan keimanan Ahli Kitab ada yang jujur dan tidak jujur, ada yang beriman tapi kebanyakan tidak beriman. Adapun sebab-sebab Ahli Kitab divonis kafir oleh Tuhan karena: mengingkari ayat-ayat Allah, mencampur-adukkan yang hak dan yang batil, menyembunyikan kebenaran, dan menyembunyikan ayat-ayat Tuhan, cenderung menyembunyikan dan membiarkan isi Kitab - karena tidak dijadikan rujukan, tidak menginginkan diturunkannya sesuatu kebaikan kepada orang-orang beriman, dan menginginkan agar orang-orang beriman kembali kafir. Adapun mahasiswa yang belajar agama dengan metode konvensional tidak memahaminya dengan tepat. Dengan demikian metode pembelajaran ini (tematik digital Quran) perlu diimplementasikan dalam perkuliahan PAI di perguruan tinggi. 


\section{Daftar Pustaka}

Ad-Darimi, Imam. 2013. Sunan Ad-Darimi (dalam Lidwa Pusaka i-software). www.lidwapusaka.com.

Afandi, Abdullah Khozin. 2001. Memahami Makna Al-Wasilata Berdasarkan Metode AlQarafi. Afkaar - Jurnal Pahingan Jamaah Lil-Muqarrabien, XIV.

al-Farmawi, Abd al-Hayy. 1977. Al-Bidayah fi al-Tafsir al-Maudhu'i. Kairo: Matba'ah alHadarah al $\neg$ Arabiyah.

al-Qattan, Manna`Khalil. 2001. Studi Ilmu-ilmu Qur’an. Terjemahan Mudzakir AS. (VI). Bogor: Pustaka Litera Antar Nusa.

al-Qurthubi, Syaikh Imam. 2007. Al-Jami` li Ahkaam Al-Quran (Tafsir Al-Qurthubi). Terjemahan Fathurrahman dkk. Jakarta: Pustaka Azzam.

Al-Sadr, Muhammad Baqir. 1990. Pendekatan Tematik terhadap Tafsir al-Qur'an. Jurnal Ilmu Dan Kebudayaan, Vol. 1 (4), 1-28.

Alu Syaikh, Abdullah bin Muhammad. 2009. Lubabut Tafsir min Ibni Katsir, terjemahan M. Abdul Ghoffar dengan judul Tafsir Ibnu Katsir. Cetakan ketujuh. Bogor: Pustaka Imam Asy-Syafi i, http://www.pustakaimamsyafii.com.

ash-Shiddieqy, Hasbi. 1972. Ilmu-Ilmu Al-Quran. Jakarta: Bulan Bintang.

ash-Shidieqi, Hasbi. 1980. Sejarah dan pengantar Ilmu Al-Qur'an/Tafsir. Jakarta: Bulan Bintang.

ath-Thabari, Ibn Jarir. 2007. Jami`Al-Bayan `an Ta`wil Ayi Al-Quran. Terjamahan Ahsan Askan dengan judul Tafsir Ath-Thabari. Jakarta: Pustaka Azzam.

Dahlan, M.D. 1990. Model-model Mengajar: Beberapa Alternatif Interaksi BelajarMengajar. Bandung: CV Diponegoro.

Digital Quran ver 3.1. 2013. Al-Quran dan Terjemahnya (Bahasa Indonesia). Al-Quran dan Terjemahnya penerbit Kementerian Agama Republik Indonesia.

Gall, Walter; Borg; and Meredith Damien. 1983. Educational Research: An Introduction; Fourth Edition (Fifth Edit). New York: Longman.

Joyce, Bruce \& Weil, M. 2009. Models of Teaching. New Jersey: Prentice-Hall Inc.

Joyce, Bruce; Weil, M., \& Calhoun, E. 2011. Models of Teaching. Terjemahan. (II). Yogyakarta: Pustaka Pelajar.

Katsir, Ibn. 1987. Tafsir Al-Qur'an Al-Karim. Beirut: Dar al-Ma'rifat. 
Khairunnisa, S., Hakam, A., \& Amaliyah, A. (2018). Pengembangan Media Pembelajaran Permainan Monopoli pada Mata Pelajaran Pendidikan Agama Islam. Tarbawy: Indonesian Journal of Islamic Education, 5(1), 60-69.

Madjid, Nurcholis. 1992. Islam, Doktrin, dan Peradaban. Jakarta: Paramadina.

Muhsin. 2010. "Perdebatan Penggunaan Hermeuneutika sebagai Metode Penafsiran AlQuran." Alqalam Lembaga Penelitian IAIN Sultan Maulana Hasanuddin Banten, Serang, Volume 27 (No. 1), 77-103.

Muthahhari, Murtadha. 2007. Manusia Dan Agama. Bandung: Mizan.

Muthahhari, Murtadha. 2009. Keadilan Ilahi: Asas Pandangan-Dunia Islam. Terjemahan Agus Efendi. Bandung: Mizan Pustaka.

Nasution, Harun. 2006. Bank Makalah: Harun Nasution dalam Seminar di Masjid IAIN Medan 11 Maret 2006. Oleh Hartono Ahmad Jaiz.

Pasha \& Darban. 2000. Muhammadiyah sebagai Gerakan Islam. Yogyakarta: LPII.

Rahmat, Munawar. 2012. Manusia Menurut Al-Quran Cenderung Mempertuhankan Hawa Nafsunya. Taklim: Jurnal Pendidikan Agama Islam, 10(2), 105-122.

Rahmat, Munawar. 2012. Manusia Menurut Al-Quran Cenderung Mempertuhankan Hawa Nafsunya. Taklim: Jurnal Pendidikan Agama Islam, 10(2), 105-122.

Rahmat, Munawar. 2015. Implementasi Metode Tematik Al-Quran untuk Memahami Makna Beriman kepada Malaikat-malaikatNya Allah. Taklim - Jurnal Pendidikan Agama Islam, Volume 13 (No.1 Maret 2015), 79-92.

Rahmat, Munawar. 2018. Model Perkuliahan Pendidikan Agama Islam Yang Damai, Moderat, dan Toleran. NADWA Jurnal Pendidikan Islam, Vol. 12 (No. 1 Juni 2018).

Rahmat, Munawar \& Fahrudin. 2016. Studi Tematik Al-Quran Tentang Makna Khalifah Fil Ardhi dan Implikasinya Terhadap Pendidikan. In M. A. Somad, M. Syafei, \& Dkk (Eds.), The 1st UPI International Conference on Islamic Education: Islamic Education Faces Global Challenges. (223-229). Bandung: Universitas Pendidikan Indonesia.

Rahmat, M., Fahrudin, \& Somad, M.A. 2017. Pengembangan Model Pembelajaran 'Studi Tematik Al-Quran' melalui Digital Quran dalam Perkuliahan PAI untuk Akselerasi Pemahaman Mahasiswa terhadap Ajaran 'Inti' Agama Islam. Laporan Penelitian Tahap III yang Dibiayai Ditjen DIKTI pada LPPM Universitas Pendidikan Indonesia.

Shihab, M. Quraisy. 2000. Wawasan Al-Quran: Tafsir Tematik atas Pelbagai Persoalan Umat. Bandung: Mizan.

Sugioyono. 2017. Metode Penelitian Pendidikan. Bandung: PT Remaja Rosdakarya bekerjasama dengan Program Pascasarjana UPI. 
Sulastri, A., Mardhiah, I., \& Ismail, Y. (2017). Pengembangan Media Ice Breaker Talking Pen pada Mata Pelajaran PAI Kelas X SMAN 100 Jakarta. Jurnal Studi AlQur'an, 13(2), 158-174..

Thabathaba`i, Sayyid Muhammad Husain. 2010. Al-Mizan. Terjemahan Ilyas Hasan. Bandung: Lentera, Cetakan pertama,

Ulfa, Maria. 2013. Mencermati Inklusivisme Agama Nurcholish Madjid. Ejournal.unida.gontor.ac.id, 11 No. 2., 11 (2). 
